\title{
Effect of Photoperiod and Ambient Temperature on Nonshivering Thermogenesis of Peromyscus maniculatus
}

\author{
David A. ZEGERS \& Joseph F. MERRITT
}

Zegers D. A. \& Merritt J. F., 1988: Effect of photoperiod and ambient temperature on nonshivering thermogenesis of Peromyscus maniculatus. Acta theriol., 33, 19: 273-281 [With 1 Table]

Deermice were exposed to photoperiods simulating either early winter photoperiod ("winter replicates") or early spring photoperiod ("spring replicates") before experiencing 14-day treatment periods designed to assess the effects of ambient temperature and photoperiod on nonshivering thermogenesis (NST). These treatments consisted of the four combinations of low $\left(5^{\circ} \mathrm{C}\right)$ or high $\left(25^{\circ} \mathrm{C}\right)$ temperatures and short $(8 \mathrm{~L}: 16 \mathrm{D})$ or long $(16 \mathrm{~L}: 8 \mathrm{D})$ photoperiod. In both winter and spring replicates, only those mice exposed to both low temperature and short photoperiod experienced significantly elevated levels of NST. In the spring replicates, those mice exposed to both high temperature and long photoperiod experienced significant loss of NST. These results support the hypothesis that photoperiod and ambient temperature interact to trigger changes in NST.

[Department of Biology, Millersville University, Millersville, PA 17551 USA (DAZ), Powdermill Biological Station, Carnegie Museum of Natural History, Rector, PA 15677 USA (JF'M)]

\section{INTRODUCTION}

For small mammals inhabiting seasonally cold environments, annual cycles in nonshivering thermogenesis (NST) provide the means of rapid heat production in response to cold (Jánský, 1973). Elevated levels of NST in winter for species that do not undergo torpor (e.g., Microtus ochrogaster, Wunder et al., 1977; Clethrionomys rutilus, Rosenmann et al., 1975; and 3larina brevicauda, Merritt, 1986) increase the cold tolerance of the individual. High capacity for NST in species that do undergo torpor also functions as a source of heat during arousal from torpor (Smith \& Horwitz, 1969). In North America, both the deermouse (Peromyscus maniculatus) and the white-footed mouse (Peromyscus leucopus) experience wintertime torpor (Hill, 1983; Tannenbaum \& Pivorun, 1984) and have annual cycles in NST capacity (Lynch, 1973; Zegers \& Merritt, in press).

Knowledge of the environmental cues triggering changes in NST is fundamental in understanding the winter survival of these small homeotherms. For Peromyscus, photoperiod and ambient temperature have been studied extensively as possible cues for a variety of physiological parameters (Hill, 1983). Winter molt, regression of gonads, adrenals and 
liver, increased occurrence of daily torpor, and hypertrophy of brown adipose tissue (BAT) of P. leucopus were stimulated by short photoperiod (Lynch, 1973; Lynch \& Gendler, 1980; Lynch et al., 1980).

Both photoperiod and ambient temperature have been linked to changes in NST. Thermogenic response of albino Mus musculus to norepinephrine (NE) was dependent upon the extent of cold exposure (Wunder, 1981); deposition of brown adipose tissue (BAT) in albino M. musculus (Heldmeier, 1975) and in P. leucopus (Lynch \& Folk, 1971) was stimulated by cold exposure. Data for C. rutilus indicate that the level of wintertime NST may vary between years, as does intensity of cold, which suggests that temperature may be important in adjusting level of NST (Feist \& Morrison, 1981). Lynch (1973) found that NST capacity of $P$. leucopus increased rapidly after the first cold period in autumn. Likewise, NST increased significantly after the first cold of autumn for both P. leucopus and P. maniculatus (Zegers \& Merritt, in press). However, because autumn is marked by both decreasing temperature and photoperiod, the relative roles of ambient temperature and photoperiod in triggering changes in NST are difficult to differentiate in acclimatization studies. In controlled laboratory experiments, NST of $P$. maniculatus was inversely correlated with ambient temperature independent of photoperiod and previous exposure to photoperiod (Sheffield \& Andrews, 1980). Likewise, P. leucopus exposed to $6^{\circ} \mathrm{C}$ for eight days developed higher NST capacity than did individuals exposed to $26^{\circ} \mathrm{C}$, although short photoperiod also increased the level of NST (Lynch, 1970).

Studies of other species support the hypothesis of photoperiod as a primary cue of NST. Length of scotophase was significant in inducing elevated NST for Rhabdomys pumilio and Lemniscomys griselda (Haim, 1982), Apodemus mystacinus (Haim \& Yahav, 1982), Phodopus sungorus (Heldmaier et al., 1982), Microtus ochrogaster (Wunder, 1984), and Dipodomys ordii (Gettinger \& Ralph, 1985), although a circannual rhythm in NST may be present in Microtus ochrogaster (Wunder, pers. comm.).

Wunder (1984) and Heldmaier et al. (1985) have proposed that photoperiod should be the more general cue because this would allow small mammals both to anticipate the first cold of winter and to prevent loss of NST capacity during periodic warm days in winter. Photoperiod may trigger seasonal changes in NST while cold exposure may improve further thermogenic capacity and, therefore, provide maximum cold tolerance in mid-winter (Heldmaier et al., 1985). Thus, the objective of this study was to assess the relative importance of photoperiod and ambient temperature in triggering changes in NST maximum in P. maniculatus. 


\section{METHODS AND MATERIALS}

All mice were live-trapped at the Biological Station of the Carnegie Museum of Natural History (Powdermill Nature Reserve) in southeastern Westmoreland County, Pennsylvania, USA. The station is located within the Allegheny Mountains of the Appalachian Plateau of Pennsylvania (Grimm \& Roberts, 1950). The study site was a relatively mature, mesic forest with a canopy composed primarily of beech (Fagus grandifolia), yellow poplar (Liriodendron tulipifera), sugar maple (Acer saccharum), and red oak (Quercus borealis) (Merritt, 1984, 1986). Mice were live-trapped in September and October, 1985, ear-tagged for identification, and taken into the laboratory. Tag number, capture site, date and time of capture, body mass, sex, and reproductive status were recorded.

Before and after the acclimation trials, the mice were housed individually at laboratory temperatures ranging from 17 to $27^{\circ} \mathrm{C}$ and under an artificial light regime which approximated the natural photoperiod (Zegers \& Merritt, in press).

NST maximum was measured between 0700 and $1600 \mathrm{hrs}$ using a positive pressure "push-through" assembly with a Beckman 755 paramagnetic oxygen analyzer (Merritt, 1986). The air flowed through columns of soda lime and drierite to remove $\mathrm{CO}_{2}$ and $\mathrm{H}_{2} \mathrm{O}$ before entering the oxygen analyzer (condition $\mathrm{B}$ of Hill, 1972); rate of air flow ( $1000 \mathrm{ml} / \mathrm{min})$ through the $3800 \mathrm{ml}$ glass animal chamber was measured by calibrated flow meters. Before and after testing, each mouse was weighed and its rectal temperature recorded.

Because norepinephrine-induced heat production is equivalent to cold-induced NST (Bockler et al., 1982), NST maximum was defined as the total metabolic response to a mass-dependent dose of $\mathrm{NE}$ and measured as the highest oxygen consumption in unanesthetized, quiescent mice at $25^{\circ} \mathrm{C}$ following an IM injection of a dose of $\mathrm{NE}$ (Levophed bitartrate injection, Winthrop-Breon, $1 \mathrm{ml}=1 \mathrm{mg}$ base). This dose $\left(\mathrm{mg} / \mathrm{kg}=\left[6.6 \mathrm{BW}^{-0.458}\right] / 2\right)$ was previously determined to elicit maximum thermogenic response in $P$. maniculatus (Wunder, pers. comm.). Metabolic rate was computed according to the method of Depocas and Hart (1957) and Hill (1972), expressed in milliliters of oxygen consumed per gram per hour $\left(\mathrm{ml} \mathrm{O}_{2} \mathrm{~g}^{-1} \mathrm{hr}^{-1}\right)$. Because RMR does not fluctuate in response to changes in either photoperiod or ambient temperature (Zegers \& Merritt, in press), we did not measure RMR and thus could not calculate NST capacity. Rather, we used NST maximum as our measure of the thermogenic abilities of the mice.

Before the experiments started, the deermice were exposed to photoperiod which simulated the decreasing photoperiod of early winter ("winter replicates"). In late January through March, additional replicates ("spring replicates") were conducted using the same individuals (as in the winter replicates). Before being used again, all mice were allowed at least four weeks of recovery under a photoperiod simulating the naturally increasing one and high temperatures $\left(16-27^{\circ} \mathrm{C}\right)$.

To assess the effects of photoperiod and ambient temperature on NST maximum, groups of mice were tested for their thermogenic response to NE immediately before and after a 14-day acclimation period. Other studies (Lynch, 1970; Wunder, 1981) indicate that 14 days of acclimtion is adequate to elicit changes in NST. Our treatments consisted of one of the following sets of conditions: (a) cold temperature $\left(5^{\circ} \mathrm{C}\right)$ and short photoperiod $(8 \mathrm{~L}: 16 \mathrm{D})$, (b) cold $\left(5^{\circ} \mathrm{C}\right)$ and long photoperiod $(16 \mathrm{~L}: 8 \mathrm{D})$, (c) warm temperature $\left(25^{\circ} \mathrm{C}\right)$ and short photoperiod $(8 \mathrm{~L}: 16 \mathrm{D})$, and (d) warm temperature $\left(25^{\circ} \mathrm{C}\right)$ and long photoperiod $(16 \mathrm{~L}: 8 \mathrm{D})$. Light intensity 


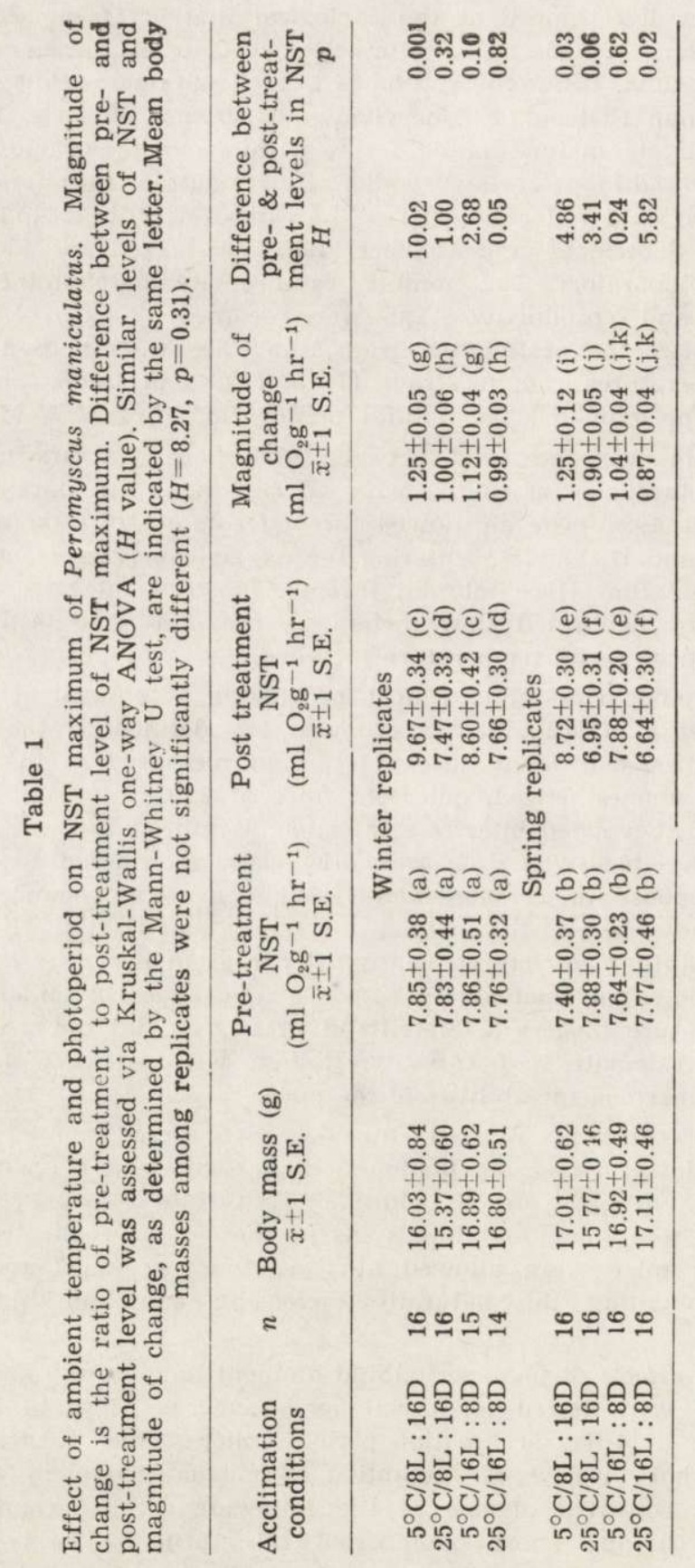


varied from 0 to 6 lux during the dark phase and from 1400 to 3200 lux during the light phase.

Four winter and four spring replicates were conducted; each replicate involved. four mice in each of the four treatments. Among the acclimation groups, the mice were matched as closely as possible for age, sex, and mass. Females obviously pregnant or lactating were not used. Temperature and photoperiod conditions of the individual chambers were switched between the replicates to reduce spurious "chamber effects" (Hurlbert, 1984). Each mouse was retested during the same hour of the day as it was originally tested in an attempt to reduce the effect of any circadian rhythm in responsiveness to NE.

Levels of NST maximum before and after the treatments were used to assess change in NST. Because some subsets of our data were not homogeneous in distribution, nonparametric tests were employed. Significant changes in NST maximum were assessed by Kruskal-Wallis one-way ANOVA and the MannWhitney $U$ test. The magnitude of change in NST maximum was measured as the ratio of post-treatment to pre-treatment values (Didow, 1972).

\section{RESULTS}

Although starting values for NST maximum were not different in the winter and spring trials $(H=0.28, p=0.60)$, ending values and the magnitude of change in NST were significantly different in the winter replicates than in those conducted in the spring (for ending values, $H=5.74, p=0.02$; for magnitude of change data, $H=4.90, p=0.03$ ). Therefore, we did not pool the data for the winter and spring replicates. In general, however, the trends are the same in those two data sets. Only those mice exposed to both low temperature and short photoperiod experienced significant increases in NST during the acclimation periods. In the spring replicates, mice exposed to both high temperature and long photoperiod experienced significant reduction in NST maximum; mice subject to other treatments experienced no significant changes in level of NST (Table 1).

For the winter replicates, starting values for the mice exposed to the four treatment conditions were not significantly different $(H=0.18$, $p=0.98$ ); however, ending values and the magnitude of change were different among the treatments (respectively, $H=19.54, \quad p=0.0002$; $H=18.56, p=0.0003)$. Mann-Whitney $\mathrm{U}$ test revealed that the mice in both low temperature treatments had significantly higher levels of NST at the end of the acclimation periods than did mice in the two high temperature treatments, regardless of exposure to photoperiod (Table 1).

Likewise, for spring replicates, starting levels of NST for mice exposed to the four treatments were not different $(H=0.47, p=0.93)$. Ending levels of NST and the magnitude of change did vary among the treatment groups (respectively, $H=20.45, p=0.0001 ; H=16.15, p=0.001$ ). MannWhitney $U$ test revealed that ending NST levels of mice in the low 
temperature treatments were significantly higher than those of mice in the two high temperature treatment groups, regardless of type of exposure to photoperiod during the acclimation periods (Table 1).

\section{DISCUSSION}

Our results may be construed as supporting the hypothesis of declining temperature as the major cue for seasonal acclimatization in NST. However, an alternative explanation is that the decreasing photoperiod of early autumn had triggered increased NST capacity before the experiments were started, and thus our experiments tested wintertime sensitivity of NST to fluctuations in photoperiod and ambient temperature rather than seasonal adjustments. Indeed, the starting values for NST in this experiment (mean $=7.89 \mathrm{ml} \mathrm{O}_{2} \mathrm{~g}^{-1} \mathrm{hr}^{-1}$ ) were equivalent to those of deermice caught and tested by Zegers and Merritt (in press) in December and January (winter mean $=7.72 \mathrm{ml} \mathrm{O}_{2} \mathrm{~g}^{-1} \mathrm{hr}^{-1} \mathrm{U}=400.5$, $p=0.91$ ) and higher than those of mice caught in summer (summer mean $=5.30 \mathrm{ml} \mathrm{O} \mathrm{g}^{-1} \mathrm{hr}^{-1}, U=76.0, p<0.001$ ). In addition, Lynch (1973) found that NST capacity in P. leucopus increased to mid-winter levels rapidly during mid-September. Thus, it seems more likely that our experiments demonstrated the wintertime sensitivity of NST to fluctuating photoperiod and ambient temperature than they demonstrated the significance of these factors in triggering seasonal changes in NST.

In all treatments, the magnitude of change was greater in the winter than in the spring replicates. This may be due to the four weeks of increasing photoperiod before the spring tests, or it may be caused by some metabolic interference due to the previous use of these individuals in these experiments. Regardless, both data sets show that both photoperiod and temperature are involved in triggering changes in NST. Other studies support this conclusion. A significant portion of the total acclimatization of $M$. ochrogaster, was not due to photoperiod alone, but a response to both environmental cues (Wunder, 1984). Similarily, 45\% of the total improvement in NST of Phodopus sungorus was due to cold stimulation and $55 \%$ due to photoperiod (Heldmaier et al., 1982). These studies and those of Feist \& Morrison (1981) for C. rutilus and Zegers \& Merritt (in press) for P. leucopus and P. maniculatus are consistent with the hypothesis that photoperiod may function as the cue for seasonal changes in NST while cold exposure may further improve thermogenic capacity, thus providing maximum cold tolerance in mid-winter. Our data for the acclimation of $P$. maniculatus are consistent with that hypothesis. Moreover, our data and similar results for P. leucopus (Lynch, 1970 ) indicate that ambient temperature and photopoeriod may interact 
to trigger the thermogenic adjustments made by these mammals. The concept of interacting cues is congruous with the hypothesis that photoperiod may act as seasonal cue while cold exposure may improve further thermogenic capacity in winter.

Acknowledgements: We thank Arlynn Adamerovich for her valuable assistance in the laboratory and field. The Faculty Academic Development Fund of Millersville University and the M. Graham Netting Research Fund of the Carnegie Museum of Natural History provided financial assistance. This research was accomplished because of a released time grant provided to D.A.Z. by Millersville University. The comments of A. J. Antipas, W. J. Yurkiewicz, and L. N. Reinking greatly improved this manuscript.

\section{REFERENCES}

1. Bockler H., Steinlechner S. \& Heldmaier G., 1982: Complete cold substitution of noradrenaline-induced thermogenesis in the Djungarian hamster, Phodopus sungorus. Experientia, 38: 261-262.

2. Depocas F. \& Hart J. S., 1957: Use of the Pauling oxygen analyzer for measurement of oxygen consumption of animals in open-circuit systems and in a shortlag, closed circuit apparatus, J. Appl. Physiol., 10: 388-392.

3. Didow L. A., 1972: Seasonal and geographic differences in cold resistance and heat production capabilities of two species of Peromyscus. Unpubl. Ph. D. dissert. Carleton Univ., Ottawa, 1-127.

4. Feist D. D. \& Morrison P. R., 1981: Seasonal changes in metabolic capacity and norepinephrine thermogenesis in the Alaskan red-backed vole: environmental cues and annual differences. Comp. Biochem. Physiol., 69A: 697-700.

5. Gettinger R. D. \& Ralph C. L., 1985: Thermoregulatory responses to photoperiod by kangaroo rats (Dipodomys ordii): influence of night lighting on nonshivering thermogenesis and resting metabolism. J. Exper. Zool., 234: $335-340$.

6. Grimm W. C. \& Roberts H. A., 1950: Mammal survey of southwestern Pennsylvania. Pennsylvania Game Comm., 1-99.

7. Haim A., 1982: Effects of long scotophase and cold acclimation on heat production in two diurnal rodents. J. Comp. Physiol., 148: 77-81.

8. Haim A. \& Yahav S., 1982: Nonshivering thermogenesis in winter acclimatized and in long-scotophase and cold acclimated Apodemus mystacinus (Rodentia). J. Therm. Biol., 7: 193-195.

9. Heldmaier G., 1975: The effect of short daily cold exposures on development of brown adipose tissue in mice. J. Comp. Physiol., 98: 161-168.

10. Heldmaier G., Steinlechner S. \& Rafael J., 1982: Nonshivering thermogenesis and cold resistance during seasonal acclimatization in the Djungarian hamster. J. Comp. Physiol., 149: 1-9.

11. Heldmaier G., Bockler H., Buchberger A., Lynch G. R., Puchalski W., Steinlechner S. \& Weisinger H., 1985: Seasonal acclimation and thermogenesis. [In: "Circulation, respiration, and metabolism", Ed. R. Gilles]. Springer Verlag, $1-610$.

12. Hill R. W., 1972: Determination of oxygen consumption by use of the paramagnetic oxygen analyzer. J. Appl. Physiol., 33: 261-263. 
13. Hill R. W., 1983: Thermal physiology and energetics of Peromyscus ontogeny body temperature, metabolism, insulation, and microclimatology. J. Mamm., 64: $19-37$.

14. Hurlbert S. H., 1984: Pseudoreplication and the design of ecological field experiments. Ecol. Monog., 54: 187-211.

15. Jánský L., 1973: Nonshivering thermogenesis and its thermoregulatory significance. Biol. Rev., 48: 85-132.

16. Lynch G. R., 1970: Effect of photoperiod and cold acclimation on nonshivering thermogenesis. Amer. Zool., 10: 308.

17. Lynch G. R., 1973: Seasonal changes in thermogenesis, organ weights, and body composition in the white-footed mouse, Peromyscus leucopus. Oecologia, 13: $363-376$.

18. Lynch G. R. \& Folk G. E., 1971: Photoperiod, temperature, and interscapular brown fat in Peromyscus leucopus. Cryobiology, 8: 203.

19. Lynch G. R. \& S. L. Gendler, 1980: Multiple responses to different photoperiods occur in the mouse, Peromyscus leucopus. Oecologia, 45: 318-321.

20. Lynch G. R., Sullivan J. K. \& Gendler S. L., 1980: Temperature regulation in the mouse, Peromyscus leucopus: effects of various photoperiods, pinealectomy, and melatonin administration. Internatl. J. Biometerol., 24: 49-55.

21. Merritt J. F., 1984: Growth patterns and seasonal thermogenesis of Peromyscus maniculatus inhabiting the Appalachian and Rocky Mountains of North Ameirca. Ann. Carnegie Mus. Nat. Hist., 53: 527-548.

22. Merritt J. F., 1986: Winter survival adaptations of the short-tailed shrew (Blarina brevicauda) in an Appalachian montane forest. J. Mamm., 67: $450-464$.

23. Rosenmann M., Morrison P. R. \& Fiest D. D., 1975: Seasonal changes in the metabolic capacity of red-backed voles. Physiol. Zool., 48: 303-310.

24. Sheffield M. V., Jr. \& Andrews V., 1980: Interactions of ambient temperature and photoperiod on deermouse (Peromyscus maniculatus) energetics. Comp. Biochem. Physiol., 67 A: 103-116.

25. Smith R. E. \& Horwitz B. A., 1969: Brown fat and thermogenesis. Physiol. Rev., 49: $330-425$.

26. Tannenbaum M. G. \& Pivorun E. B., 1984: Differences in daily torpor patterns among three southeastern species of Peromyscus. J. Comp. Physiol., B, 154: 233-236.

27. Wunder B. A., 1981: Effects of short-term, daily, cold exposure on brown adipose tissue and nonshivering thermogenesis in the house mouse and prairie vole. Acta Univ. Carolinae, Biol., 1979: 315-318.

28. Wunder B. A., 1984: Strategies for and environmental cueing mechanisms of seasonal changes in thermoregulatory parameters of small mammals. [In: "Winter ecology of small mammals", Ed. J. F. Merritt). Spec. Publ. Carnegie Mus. Nat. Hist., 10: 380 pp.

29. Wunder B. A., Dobkin D. S. \& Gettinger R. D., 1977: Shifts of thermogenesis in the prairie vole (Microtus ochrogaster): strategies for survival in a seasonal environment. Oecologia, 29: 11-26.

30. Zegers D. A. \& Merritt J. F., (In press): Winter survival adaptations of Peromyscus in an Appalachian montane forest. J. Mamm.

Received 3 August 1987, Accepted 26 January 1988. 
David A. ZEGERS i Joseph F. MERRITT

WPEYW FOTOPERIODU I TEMPERATURY OTOCZENIA NA NIEDRESZCZOWA TERMOGENEZE U PEROMYSCUS MANICULATUS

\section{Streszczenie}

Osobniki Peromyscus maniculatus trzymano w warunkach fotoperiodu wczesnej zimy (zimowe powtórzenia) lub wczesnej wiosny (wiosenne powtórzenia). Następnie przez 14 dni poddawano je wpływowi niskiej $\left(5^{\circ} \mathrm{C}\right)$ lub wysokiej $\left(25^{\circ} \mathrm{C}\right)$ temperatury i równocześnie krótkiego (8 godz.) lub długiego (16 godz.) dnia. Zarówno w zimowych jak i w wiosennych powtórzeniach jedynie osobniki poddawane równocześnie dzialaniu niskiej temperatury i krótkiego dnia wykazywały istotnie wyższy poziom niedreszczowej termogenezy. W powtórzeniach wiosennych u osobników trzymanych w wysokiej temperaturze $\mathrm{i}$ w warunkach długiego dnia poziom niedreszczowej termogenezy spadal (Tabela 1). Wyniki te potwierdzają hipotezę, że fotoperiod i temperatura wspóldziałają przy wyzwalaniu zmian niedreszczowej termogenezy. 